LAWRENCE B. KRAUSE

Brookings Institution

assisted by JOHN A. MATHIESON

Brookings Institution

\title{
How Much of Current Unemployment Did We Import?
}

IN THE FIRST QUARTER OF 1970, unemployment in the United States rose to 4 percent of the labor force, the presumed full employment target. By the first quarter of 1971, unemployment reached the undesirable level of nearly 6 percent. Over this same one-year period, imports into the United States increased by $\$ 4$ billion (1971:1 over 1970:1 at annual rates) and exports increased by only $\$ 3$ billion, reducing the net positive trade balance by $\$ 1$ billion. An increase of competitive imports-considered in isolation -has the direct consequence of reducing job opportunities. A reduction of exports has a similar job-destruction effect. By the same token, a reduction of imports and an increase of exports have the opposite consequence on job opportunities. In view of the trade development, a seemingly natural question is how much of current unemployment did we import? ${ }^{1}$

Actually the question is not as natural as it appears because international trade cannot be considered in isolation from other economic developments. In an efficiently evolving dynamic economy, job opportunities are constantly being lost because of many factors, but the losses are more than offset by job-creating developments. Shifts in consumer demand, changes in productive technology, restructuring of government expendi-

1. Some observers have already given their answers to it. See, for example, AFL-CIO, Industrial Union Department, Crisis: Imports vs. Jobs (Viewpoint, Vol. 1, Summer 1971). 
tures, as well as increases in imports, cause unemployment among domestic workers whose product is no longer needed. General unemployment need not occur, however, as long as aggregate demand is maintained in the economy, if need be through governmental policy. In the particular events of 1970-71, full employment was not maintained and, therefore, the contribution of the decline of net exports to the increase in unemployment becomes meaningful. To be sure, the employment effects of the decline of net exports could have been offset by appropriate fiscal stimulation, but it can be argued that trade movements are relatively unpredictable and, therefore, some unintended unemployment may have resulted.

It is not legitimate, however, to count the entire decline in net exports since 1964 as a cause of current unemployment. Up to 1970, displaced workers in the aggregate were absorbed elsewhere in the economy and did not create an unemployment problem as such. Indeed, while the trade balance was declining from $\$ 6.8$ billion in 1964 to $\$ 0.7$ billion in 1969, unemployment also declined from 5.2 percent to 3.5 percent.

In addition to the issue of total employment, the economic welfare of the society depends on what kind of job opportunities are created in exchange for those being destroyed. When specific jobs are lost through technological change, for instance, there is a presumption that economic welfare is improved even though the workers actually displaced may not find equally remunerative work. A similar presumption, based on the theory of comparative advantage, exists concerning disturbances arising from international trade. Society's welfare should improve even though the individuals displaced may suffer a loss. This presumption, however, is dependent on the country's having an equilibrium exchange rate. An overvalued exchange rate would not directly prevent a country from reaching full employment; but at full employment, resource utilization would be distorted away from tradable goods toward nontradable goods and services with resulting welfare loss for the world as a whole.

\section{Methodology}

The purpose of this exercise is to obtain an estimate of the employment consequences of the decline in U.S. net exports between the first quarter of 1970 and the first quarter of 1971, the period in which unemployment rose. The first step in the estimation process was to record the changes in exports and imports at annual rates. Because different products have widely dif- 
ferent labor inputs, some disaggregation was required. Since the intention is to relate trade changes to employment levels, the classification scheme utilized in employment reports was adopted as shown in Tables 1,2 , and $3 .^{2}$ The trade statistics were taken from the Census report by end-use categories and aggregated to reach the proper classification. ${ }^{3}$ The trade data are given in Table 1, with exports and imports shown separately. Since the data come from Census reports, they differ from the merchandise totals reported in the balance of payments because they are unadjusted for timing and coverage. Furthermore, the rise in military sales ( $\$ 307$ million annual rate) and unclassified exports ( $\$ 131$ million annual rate) have been excluded from exports. The growth of unclassified imports was similarly excluded ( $\$ 267$ million), as was the decline of noncompetitive imports like coffee (\$127 million) since these declines did not lead to increases in American production. The resulting increases were $\$ 4.1$ billion in imports and $\$ 3.1$ billion in exports.

The second step in the estimation process was to evaluate the number of jobs lost and jobs gained as a result of the trade changes. There is both a direct job effect within the trade-impacted industry and an indirect effect in industries supplying inputs to it. ${ }^{4}$ The technical coefficients for both the direct and indirect employment effects were taken from a study by the Bureau of Labor Statistics. ${ }^{5}$ This study is based on the 1958 input-output tables, but projected to 1970 based on trends in productivity. The prices are also on a 1958 base, which causes some difficulty. One would like to deflate the trade values by indexes of prices of imports and exports. But since indexes of traded goods of individual industries are not available, no adjustment was made. This will tend to bias upward the estimates of both jobs lost and jobs gained, but probably will not be very significant on the net balance. ${ }^{6}$

2. Employment and Earnings, Vol. 18 (July 1971).

3. U.S. Bureau of the Census, Highlights of U.S. Export and Import Trade, FT990 (March 1970), and Highlights of Exports and Imports, FT990 (March 1971).

4. Walter S. Salant and Beatrice N. Vaccara, Import Liberalization and Employment (Brookings Institution, 1961).

5. U.S. Bureau of Labor Statistics, Projections 1970: Interindusiry Relationships, Potential Demand, Employment, Bulletin 1536 (1966), Table V-2.

6. As a crude check on the direct employment consequences, net value added per employee was calculated, based on 1969 prices from the Annual Survey of Manufactures, and used to estimate the direct employment consequences of trade changes. The results were not significantly different on balance, but they show larger absolute numbers of jobs lost and jobs gained. See Bureau of the Census, Annual Survey of Manufactures, 1969: General Statistics for Industry Groups and Industries, M69(AS)-1 (1971). 


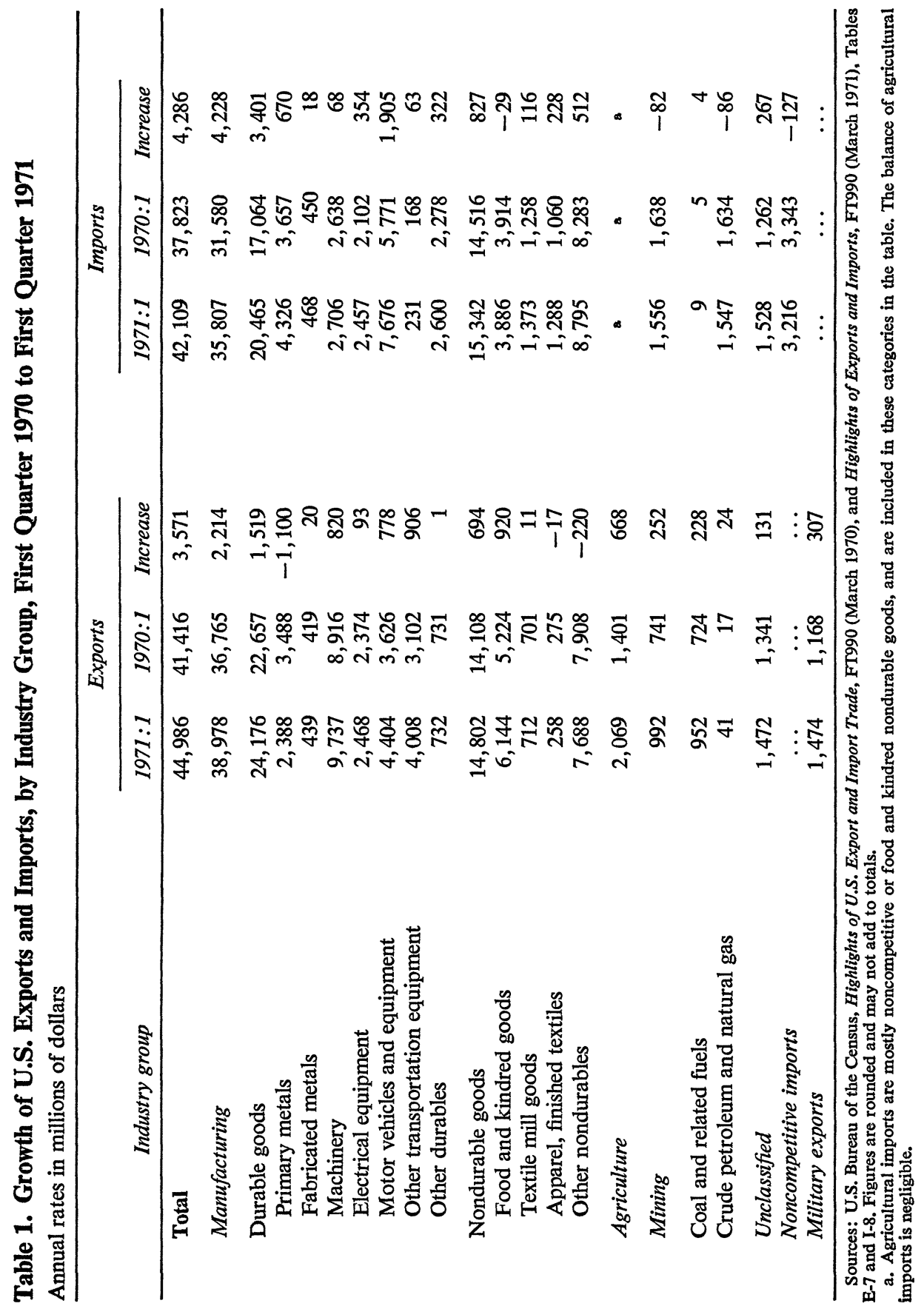




\section{Findings}

The consequences of the trade changes for employment are shown in Table 2. In direct employment, an estimated 47,800 jobs were lost due to decreases in some exports and 134,400 jobs were lost due to increases of imports, making a total loss of 182,200 jobs. However, 181,400 jobs were gained through increases in exports and a further 1,300 jobs were created through some import declines, making a total of 182,700 job increases. Thus there was on balance a slight edge toward job creation when direct employment effects are taken by themselves.

The inclusion of indirect effects shifts the balance slightly toward job destruction. There was a net loss of about 17,100 jobs due to indirect effects $(227,600$ losses, offset in part by 210,600 job gains). It is reasonable to expect the indirect effects to be more unfavorable to employment than the direct effects. Much of the growth of exports was in agriculture and mining. In both of these industries, the ratio of value added within the industry to total sales is much higher than it is in manufacturing, where most of the import increases were recorded. Since the indirect employment effects come from that portion of sales value not added by the industry itself, the observed differential was to be expected.

When the direct and indirect effects are taken together, a loss of 16,600 jobs between 1970:1 and 1971:1 can be attributed to changes in exports and imports. If the displaced workers stayed in the labor force and were not absorbed into employment, then approximately 16,600 people were added to the unemployment rolls from this cause. During this span, total unemployment rose by 1.7 million persons. Thus international trade contributed less than 1 percent of the increase. To put the results somewhat differently, if unemployment had increased only because of trade dislocations, the unemployment rate would have risen from 4.16 percent to 4.18 percent, ${ }^{7}$ rather than to the actual 1971:1 average of 5.93 percent. The net job loss may appear surprisingly small, given the decline in net exports. But it should be remembered that U.S. exports are labor-intensive relative to U.S. imports, as Leontief established and others subsequently confirmed. ${ }^{8}$ The United States need not have balanced increases in exports and

7. Assuming no change in the labor force.

8. See comments in William H. Branson and Helen B. Junz, "Trends in U.S. Trade and Comparative Advantage," this volume. 


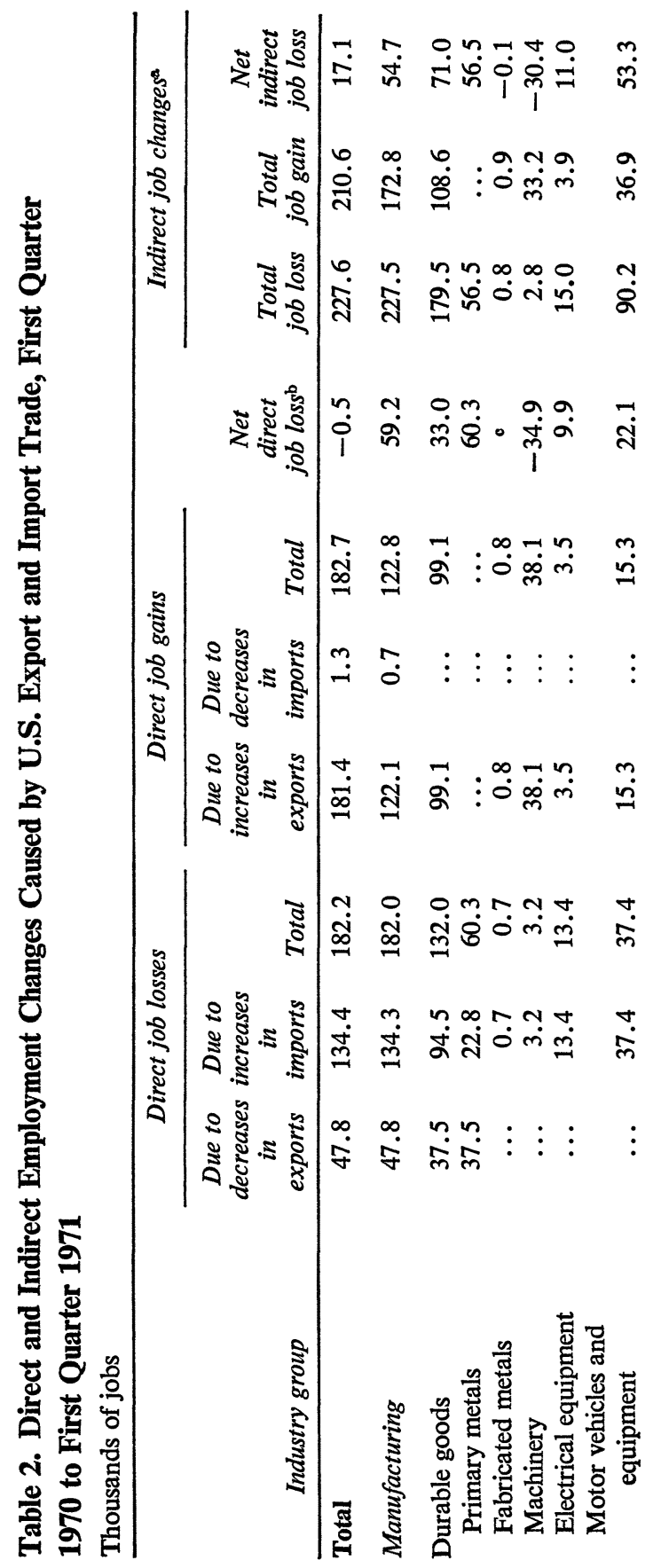




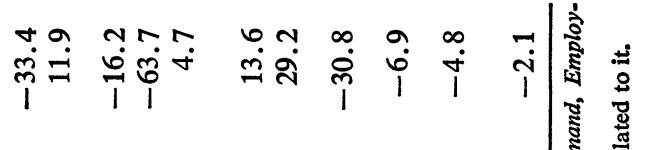

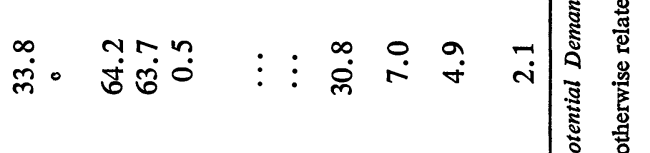

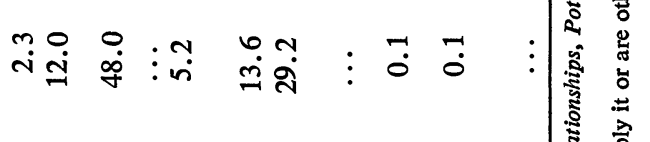

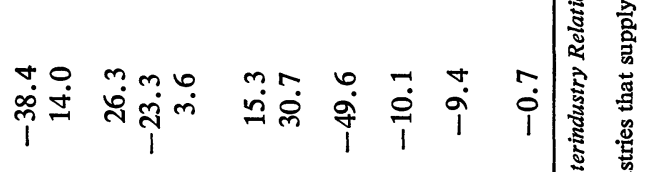

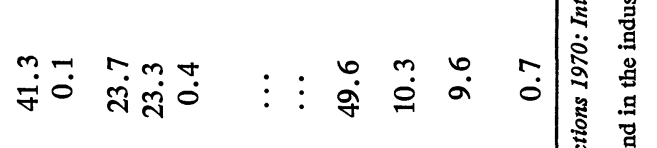

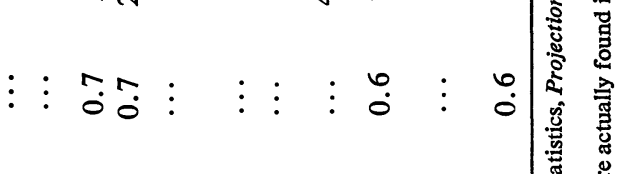

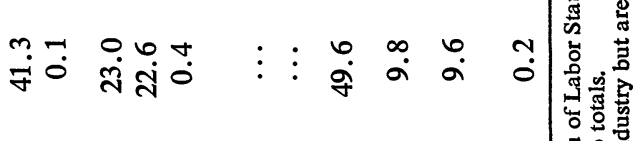

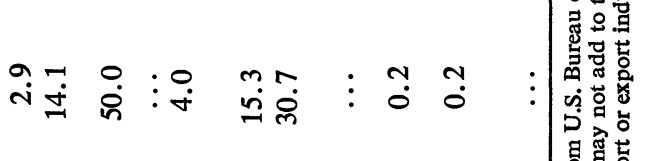

$$
\begin{aligned}
& \text { 产示 }
\end{aligned}
$$

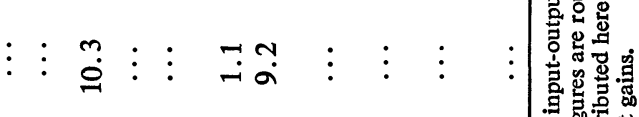


imports to maintain employment in trade-related industries. If imports increase more than exports, as occurred in the period under investigation, job losses may not occur.

While only an insignificant portion of total unemployment can be attributed to international trade, the employment situation in particular industries could be greatly affected. Table 3 relates the net direct job changes due to trade to the employment situation in specific industries. Only direct job effects were used since indirect effects are spread widely throughout the economy. As is seen, employment was down 4.6 percent in primary metals (mainly steel); 2.5 percent in motor vehicles; and about 1.5 percent in textiles. On the other hand, coal mining gained 6.6 percent in employment; other transportation equipment (mainly aircraft), 4.4 percent; and machinery, 2.0 percent. These data suggest that a good case can be made for adjustment assistance to industries that are seriously affected by imports. However, the imposition of import barriers is very dangerous since it usually leads to retaliation, which can have serious consequences on export industries. The difficulties imports cause textile firms are well known, but little attention is paid to the effect on the hard-pressed aircraft industry if it could not export.

\section{QUALIFICATIONS}

The interpretation of these findings requires certain qualifications. First, with an expanding labor force, the avoidance of job destruction is not enough to ensure full employment: Jobs must be created in sufficient numbers to accommodate new workers. Thus, even though international trade did not destroy many jobs on balance, neither did it carry its weight in creating jobs for the new entrants into the labor force. Second, even when the total number of jobs created is equal to the total destroyed, if the absolute numbers are large, frictional unemployment could increase. To establish this point, the variance of employment due to changes in international trade must be compared with the variance in employment from all other causes, and this calculation was not made. Finally, net income flows in the economy were reduced by $\$ 1$ billion due to the decline in net exports of goods, and the multiplier effects on employment were not estimated. However, these reductions were more than offset by the $\$ 2.7$ billion rise in net exports of services during the same period. In any event, the multiplier effects would be small in an economy as large as that of the United States and impossible to calculate because expenditure patterns cannot be traced. 
Table 3. Employment, with and without Effects of Changes in Export and Import Trade, by Industry Group, First Quarter 1971

Thousands of persons, seasonally adjusted

\begin{tabular}{|c|c|c|c|c|}
\hline Industry group & $\begin{array}{c}\text { Average } \\
\text { employment, } \\
1971: 1^{\mathrm{a}}\end{array}$ & $\begin{array}{l}\text { Net } \\
\text { primary } \\
\text { job loss } \\
\text { due to } \\
\text { changes in } \\
\text { export and } \\
\text { import } \\
\text { trade }\end{array}$ & $\begin{array}{l}\text { Potential } \\
\text { employment } \\
\text { without } \\
\text { trade } \\
\text { effect }\end{array}$ & $\begin{array}{l}\text { Job loss as } \\
\text { percentage } \\
\text { of potential } \\
\text { employ- } \\
\text { ment }\end{array}$ \\
\hline $\begin{array}{l}\text { Total } \\
\text { Trade related }\end{array}$ & $\begin{array}{l}74,027.2 \\
22,536.4\end{array}$ & $\begin{array}{l}-0.5 \\
-0.5\end{array}$ & $\begin{array}{l}74,026.7 \\
22,535.9\end{array}$ & $\begin{array}{l}\text { b } \\
\text { b }\end{array}$ \\
\hline Manufacturing & $18,749.2$ & 59.2 & $18,808.4$ & $0.3 \%$ \\
\hline $\begin{array}{l}\text { Durable goods } \\
\text { Primary metals } \\
\text { Fabricated metals } \\
\text { Machinery } \\
\text { Electrical equipment } \\
\text { Motor vehicles and equipment }{ }^{\circ} \\
\text { Other transportation equipment }{ }^{\circ} \\
\text { Other durables }\end{array}$ & $\begin{array}{r}10,100.8 \\
1,255.3 \\
1,327.7 \\
1,806.0 \\
1,791.0 \\
879.5 \\
914.3 \\
2,127.0\end{array}$ & $\begin{array}{r}33.0 \\
60.3 \\
0.0 \\
-34.9 \\
9.9 \\
22.1 \\
-38.4 \\
14.0\end{array}$ & $\begin{array}{r}10,133.8 \\
1,315.6 \\
1,327.7 \\
1,771.1 \\
1,800.9 \\
901.6 \\
875.9 \\
2,141.0\end{array}$ & $\begin{array}{r}0.3 \\
4.6 \\
\ldots \\
-2.0 \\
0.5 \\
2.5 \\
-4.4 \\
0.7\end{array}$ \\
\hline $\begin{array}{l}\text { Nondurable goods } \\
\text { Food and kindred goods } \\
\text { Textile mill goods } \\
\text { Apparel, finished textiles } \\
\text { Other nondurables }\end{array}$ & $\begin{array}{r}8,648.4 \\
1,781.3 \\
946.7 \\
1,378.7 \\
4,541.7\end{array}$ & $\begin{array}{r}26.3 \\
-23.3 \\
3.6 \\
15.3 \\
30.7\end{array}$ & $\begin{array}{r}8,674.7 \\
1,758.0 \\
950.3 \\
1,394.0 \\
4,572.4\end{array}$ & $\begin{array}{r}0.3 \\
-1.3 \\
0.4 \\
1.1 \\
0.7\end{array}$ \\
\hline Agriculture & $3,380.0$ & -49.6 & $3,330.4$ & -1.5 \\
\hline Mining, total & 624.0 & -10.1 & 613.9 & -1.6 \\
\hline $\begin{array}{l}\text { Mining, trade related } \\
\text { Coal and related fuels } \\
\text { Crude petroleum and natural gas }\end{array}$ & $\begin{array}{l}407.2 \\
152.9 \\
254.3\end{array}$ & $\begin{array}{r}-10.1 \\
-9.4 \\
-0.7\end{array}$ & $\begin{array}{l}397.1 \\
143.5 \\
253.6\end{array}$ & $\begin{array}{l}-2.5 \\
-6.6 \\
-0.3\end{array}$ \\
\hline Services & $48,043.0$ & $\cdots$ & $48,043.0$ & $\cdots$ \\
\hline Contract construction & $3,231.0$ & $\cdots$ & $3,231.0$ & $\cdots$ \\
\hline
\end{tabular}

Source: Employment and Earnings, Vol. 18 (July 1971). Figures are rounded and may not add to totals. a. Quarterly average.

b. Less than 0.05 percent.

c. Not seasonally adjusted. 


\section{Jobs and Dollar Devaluation}

One of the pillars of the new economic policy announced by President Nixon on August 15, 1971, was a group of measures that should lead to the devaluation of the dollar. As noted above, this should improve economic welfare from international trade, since the dollar was overvalued. The devaluation will also stimulate U.S. exports. Domestic employment will rise as a direct consequence of the devaluation, for U.S. exports will be stimulated by it, and as imports rise in price, Americans should switch consumption toward domestically produced goods. It is important to recognize, however, that the devaluation is desirable not to alleviate unemployment, but because the dollar was overvalued, as evidenced by the disequilibrium in the overall U.S. balance of payments. At full employment, there will not be more jobs because of the devaluation, but different jobs. Employment in trade-related industries will be greater and employment in purely domestic industries will be lower because of it. The most fundamental principle of the International Monetary Fund is that depreciation of a currency should not be used to correct an unemployment problem, for that merely exports the unemployment to a nondepreciating country, a practice that can lead to competitive devaluations and a host of other beggar-my-neighbor policies.

There is an important tie, however, between the timing of a devaluation and the existence of unemployment. Devaluation by itself is stimulative and inflationary. Countries usually combine devaluation with monetary and fiscal policies designed to offset the stimulation so as not to lose through domestic inflation the competitive gain they achieve via devaluation. Given the current slack in the U.S. economy, the stimulative consequences of devaluation can be accommodated through greater production, but the direct inflationary effects will still be of some concern as the higher U.S. prices of imported goods raise the price level.

As part of the new economic policy, President Nixon imposed a temporary 10 percent import surcharge, presumably for the purpose of urging other countries to appreciate their currencies to effectuate the dollar devaluation the United States seeks. It should be noted, however, that the surcharge interferes with the formulation of a new pattern of exchange rates via market action since it artificially strengthens the dollar, as does the maintenance of capital controls. Permanent restrictions on trade merely 
maintain an overvalued dollar, thus sacrificing exports while restraining imports and on balance reducing job opportunities for Americans.

\section{Conclusion}

How much of current unemployment did we import, then? None, apparently, or at most an insignificantly small portion. Domestic economic policy must take the blame for the overall unemployment situation. Nevertheless, individual industries are greatly affected by shifts in trade, some losing employment and some gaining it. Public policy should help ease the burden of adjustment to shifts in trade as it should for other causes of unemployment.

The proper policy instruments for dealing with general unemployment are monetary and fiscal policies. Since these work best when used in tandem, monetary policy cannot be, as is sometimes suggested, separately targeted for balance-of-payments purposes-at least not without significant costs. Monetary and fiscal policy must be free of external constraints, and this can be accomplished by keeping exchange rates at equilibrium values. Maintaining equilibrium will require some flexibility in spot exchange rates. With equilibrium exchange rates, one need not worry about the employment effects of a declining trade balance. Clearly, politicians must forgo the simplistic but appealing tie between imports and unemployment if a viable international system is to be maintained.

\section{Discussion}

WALTBR SALANT FOUND IT difficult to interpret the question Krause was posing. He felt that the issue on the import side was better phrased in terms of the change in the propensity to import rather than the change in the volume of imports. Since real imports rose despite the recession and the great cut in use of capacity when they would have been expected to fall, the actual rise in imports understates the rise in the propensity to import. Analytically, the Krause approach is similar to the failure to distinguish between induced and autonomous changes in fiscal policy, using the change in the actual budget deficit or surplus instead of the change in the full em- 
ployment budget as an indicator. Krause agreed that a measurement of the shift in the import function would be an interesting exercise, but a much more ambitious-and perhaps impractical—one.

Robert Hall expressed another concern about the question posed in the title of the paper. In general, a rise in unemployment is not matched by a complementary reduction of employment. In point of fact, employment has been essentially on a plateau in 1970-71, but unemployment rose because jobs did not increase as the labor force expanded. Secondly, even in a recession, much unemployment is caused by people changing jobs, and, as Krause showed, altered patterns of exports and imports forced people to change jobs. Krause acknowledged these points, noting that his exercise was intended to refute some invalid claims that were framed in terms of unemployment and were equally subject to Hall's criticisms.

Warren Smith and Charles Bischoff emphasized that an adverse shift of the trade balance could have negative secondary effects on employment through the multiplier, even if the primary effect were zero. The multiplier attaches to the primary change in income, which is negative, rather than to the primary change in employment.

Salant wished to qualify Krause's proposition that devaluation is not a proper tool for curing unemployment. While he agreed in general, he felt that, to the extent that unemployment is due to overvaluation of the currency, restoration of high employment by devaluation is preferable to a cure by monetary and fiscal expansion. The assumption underlying that proposition is that resource allocation with a proper valuation of the currency is in some sense optimal; if that assumption is valid, devaluation tends to restore that allocation. 